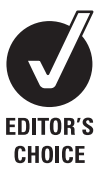

${ }^{1}$ School of Health and

Rehabilitation Sciences, University of Queensland, Brisbane, Australia

${ }^{2}$ Australian Institute of Sport,

Canberra, Australia

${ }^{3}$ McGill University, Montreal,

Canada

${ }^{4}$ Northern Arizona University,

Flagstaff, Arizona, USA

\section{Correspondence to}

Professor Bill Vicenzino,

School of Health and

Rehabilitation Sciences,

Division of Physiotherapy, The

University of Queensland,

Brisbane OLD 4072, Australia;

b.vicenzino@uq.edu.au

Accepted 4 November 2009

\title{
Foot orthoses and gait: a systematic review and meta-analysis of literature pertaining to potential mechanisms
}

\author{
Kathryn Mills, ${ }^{1,2}$ Peter Blanch, ${ }^{2}$ Andrew R Chapman, ${ }^{1-3}$ Thomas G McPoil, ${ }^{4}$ \\ Bill Vicenzino ${ }^{1}$
}

\begin{abstract}
This article systematically reviews the available literature to improve our understanding of the physiological basis for orthoses under the kinematic, shock attenuation and neuromotor control paradigms. The propositions made under these three paradigms have not been systematically reviewed collectively, and as such, there is no single-point synthesis of this clinically relevant body of evidence and somewhat disparate findings. Our comprehensive search strategy yielded 22 papers. Under each paradigm, the role of orthoses with different design features including combinations of posting, moulding and density was analysed. Where possible, data have been pooled to provide an increased level of confidence in findings. The main findings in the kinematic paradigm were that posted non-moulded orthoses systematically reduced peak rearfoot eversion $\left(2.12^{\circ}\right.$ (95\% $\mathrm{Cl} 0.72$ to 3.53$\left.)\right)$ and tibial internal rotation $\left(1.33^{\circ}\right.$ (0.12 to 2.53)) in non-injured cohorts. In the shock attenuation paradigm, it was found that non-posted moulded and posted moulded orthoses produced large reductions in loading rate and vertical impact force when compared with a control and to a posted non-moulded orthosis. The neuromotor control paradigm seems to be the least conclusive in its outcome. Based on our review, this paper concludes

is a major contributor to overuse injuries ${ }^{14-16}$ and orthoses are proposed to reduce impact force by acting as a cushioning interface between the ground and foot. More recently, the neuromotor control paradigm has been proposed, whereby an orthosis may optimise performance and minimise muscle activity and fatigue by providing input through the sole of the foot. 8917

A source of confusion for both the researcher and clinician is the array of materials with various properties (type, density or hardness/firmness) that are either custom moulded or prefabricated into various shapes, which can be further customised by the addition of posting or wedging so as to tilt the device from the horizontal. A systematic review of the literature is timely to provide a critically evaluative synthesis of the physiological basis for orthosis therapy during gait under the kinematic, shock attenuation and neuromotor control paradigms. There is no other single source of evidence of the data synthesised from these paradigms, although there are isolated systematic reviews without meta-analyses available. ${ }^{8} 1218-21$ This will assist clinicians in their prescription and fitting of orthoses and highlight areas for future research.
\end{abstract} with rudimentary guidelines for the prescription of orthosis, that sports medicine practitioners may use in their clinical decision-making process. The need for further research focusing on the role of injury, particularly in neuromotor control modification and long-term adaptation to orthoses, was highlighted.

Inshoe foot orthoses are frequently used by clinicians ${ }^{1-3}$ in the management of overuse injuries. The Australian Podiatry Council and American College of Foot and Ankle Orthopedics and Medicine $^{3}$ define "an orthosis as an appliance to support, align, correct deformity or motion of parts of the body." ${ }^{1}$ The conventional kinematic paradigm, on which these definitions are founded, is based on the hypothesis that abnormal pronation of the subtalar joint contributes to lower limb injuries and that orthoses normalise pronation and subsequent coupled movements (eg, internal tibial rotation). ${ }^{4-6}$ However, this has been questioned. ${ }^{7-11}$

In addition to the kinematic paradigm, two other major paradigms have been proposed ${ }^{81213}$; which are essentially the shock attenuation and neuromotor control paradigms. The former is based on the concept that the magnitude of force during impact

\section{METHODOLOGY \\ Search strategy}

We undertook a comprehensive, sensitive literature search strategy of Sportsdiscus, Medline, Cinahl, PubMed, Cochrane and Pedro databases from 1971 to September 2008 (fig. 1). Keywords used in the search strategy focused on the three identified paradigms: "ortho", insole, shoe, foot, electromyography (EMG), muscle activity, biomechanics, kinetic, kinematic, shock attenuation, shock absorption, overuse injur*, leg, lower limb," with no language restriction. Reference lists of reviews in similar topics and papers that met the inclusion criteria were hand searched (K.M.). Titles and (where necessary) abstracts retrieved by initial search were screened (K.M.), with only clinical trials meeting initial criteria considered for further review.

\section{Inclusion and exclusion criteria}

Included studies focused on the mechanism of action, rather than efficacy. Excluded were cohorts with neurological (eg, cerebral palsy), systemic (eg, diabetes and rheumatoid arthritis) and degenerative (eg, osteoarthritis) conditions, because these may complicate the analysis of gait. 


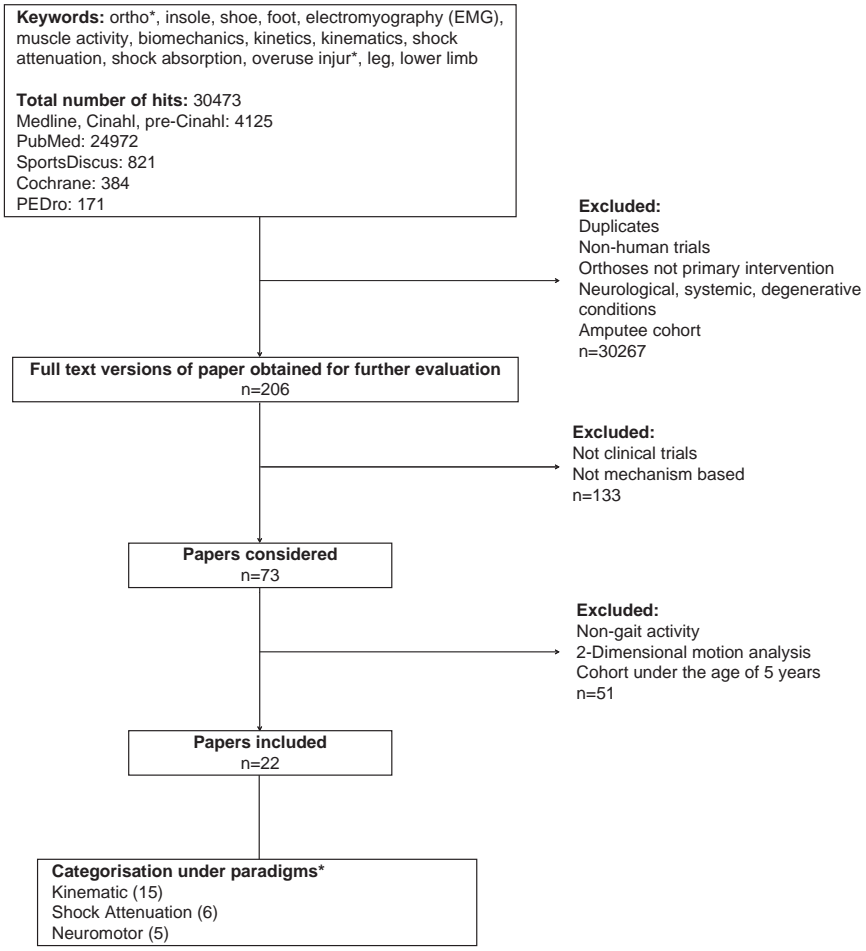

Figure 1 Search strategy; *, three studies categorised in both kinematic paradigm and shock attenuation; one study categorised in both kinematic and neuromotor control paradigm.

For each paradigm, papers examining tasks other than gait were excluded because the kinematics, kinetics, muscle activity and shock attenuation in activities such as landing, step-ups, single-leg squats and balance assessments are too dissimilar to gait and often too heterogeneous for pooling. ${ }^{22} 23$ Papers studying three-dimensional kinematics were only included because with two-dimensional analysis, movement in the frontal plane is strongly affected by the alignment of the foot in the transverse plane. ${ }^{424-26}$

\section{Quality assessment}

Since there is no validated quality assessment tool suitable for the repeated-measures, laboratory-based study designs included in our review, we adapted the Quality Index, ${ }^{27}$ which is purported to be superior because it encompasses a profile of scores for rating: reporting, internal validity, power and external validity. ${ }^{27}$ However, we only used relevant items, such as the reporting items, external validity items $11-13$, internal validity (bias) items 14-16 and 18-20 and internal validity (confounding) items 26 and 27. A score for participant characteristics (item 3) was only recorded if studies described participants' injury type, physical activity levels and foot posture. Randomisation (item 23), as described in the Quality Index, was not applicable to all studies (eg, within- participants), so we quarantined it from the overall score and modified it, awarding studies a point if the order of intervention(s) and control were randomised. The maximum score obtainable was 28 from the index.

\section{Data synthesis}

Quantitative data synthesis was conducted using Cochrane Review Manager (V.5) with data extracted directly from the papers, and when not available, we attempted to contact the authors. Mean difference between orthosis and comparator conditions and its $95 \%$ confidence interval (CI) was calculated. CI containing " 0 " represents a null effect. Estimates of the treatment effect are also provided in the form of an effect size (ES; difference in mean scores divided by pooled SD), ${ }^{28}$ and classified as trivial (0-0.2), small (0.2-0.6), moderate (0.6-1.2) and large $(>1.2),{ }^{28}$ thereby allowing a common metric across all measures.

\section{RESULTS \\ Search results}

Twenty-two papers that studied 30 different designs of orthoses on 34 kinematic and 18 kinetic variables were included (table 1). Analysis only included kinematic or kinetic variables that were investigated by more than three papers.

We categorised orthoses into three categories: (1) posted non-moulded, which refers to orthoses that were not contoured to the participant's foot (eg, flat) but with added posting; (2) non-posted moulded, which refers to orthoses that were custom made or contoured to the individual but with no posting; and (3) posted moulded that had both custom-contouring and additional posting. Density was not included in this categorisation, nor orthoses that had an irregular surface (several inbuilt raised areas), but were reported separately.

Studies were further categorised with regard to injury status of the cohorts: (1) no history of injury; (2) history, where participants were injured before orthosis prescription but were improving or asymptomatic during the study; and (3) currently injured. In addition, gait was divided into walking and jogging. Data pooling was conducted when investigations were the same across orthosis design, injury status and gait (ie, walking or jogging). Comparisons were also made either between an orthosis and a control (shoe, running sandal, flat ethylene-vinyl acetate (EVA) insert) or between two orthoses with different designs (posting; moulding; density; location of posting, eg, anterior, lateral, posterior, medial; height of posting, eg, inverted, $4^{\circ}$, etc).

\section{Quality}

Quality index scores ranged from 17 to 24, of a possible 28 (mean 20.4; table 2). Studies scored similarly in their reporting styles. Sixteen of the 22 papers presented sufficient data to extract and calculate point estimates of effect (eg, mean and SD/error or ES). Only eight studies attempted to describe adverse or longer-term effects of wearing orthoses. For internal and external validity, all studies performed poorly in three items: (1) generalisability of the sample (item 12), (2) blinding participants (item 14), and (3) blinding assessors (item 15). Thirteen papers randomised the order of intervention(s) and control.

\section{Kinematic effects on the foot and shank}

Fifteen papers presented kinematic and kinetic outcomes, studying 29 different orthosis designs, with kinematic variables of rearfoot eversion, tibial internal rotation, and rearfoot eversion velocity (tables 3-5) and kinetic variables of maximum ankle inversion moment and maximum knee external rotation moment (table 6 ).

\section{Orthoses versus control \\ Rearfoot eversion}

We found 38 comparisons of an orthosis versus a control. Of these, 28 involved orthoses of various posting and moulding designs. A further four comparisons investigated a semicustom orthosis described as a "mould-of best-fit," 29 five comparisons involved different density materials and one comparison 
Table 1 Studies included in the review

\begin{tabular}{|c|c|c|c|c|c|c|c|c|c|}
\hline Author & Activity & $\begin{array}{l}\text { N-total } \\
\text { (sex) }\end{array}$ & $\begin{array}{l}\text { Injury } \\
\text { history* }\end{array}$ & $\begin{array}{l}\text { Previous } \\
\text { orthosis } \\
\text { experience } \\
\text { (mo) }\end{array}$ & Paradigm & Intervention & $\begin{array}{l}\text { Review } \\
\text { category }\end{array}$ & Control & Comments \\
\hline Branthwaite et $a /^{32}$ & Walking & $9 \mathrm{M}$ & 1 & 0 & Kinematic & $\begin{array}{l}\text { (a) Biplanar: tilts } \\
\text { calcaneus in frontal } \\
\text { and sagittal planes; } \\
\text { (b) Cobra: feature and } \\
\text { arch profile and heel cup }\end{array}$ & $\begin{array}{l}\text { Posted } \\
\text { non-moulded, } \\
\text { Posted } \\
\text { non-moulded }\end{array}$ & $\begin{array}{l}\text { Running } \\
\text { sandal }\end{array}$ & $\begin{array}{l}\text { Insufficient data } \\
\text { to calculate } \mathrm{Cl}\end{array}$ \\
\hline Butler et $a l^{41}$ & Jogging & 15 & 1 & 0 & $\begin{array}{l}\text { Shock } \\
\text { attenuation }\end{array}$ & $\begin{array}{l}\text { (a) Suborthlene: rigid; } \\
\text { (b) EVA foam: soft }\end{array}$ & $\begin{array}{l}\text { Posted } \\
\text { non-moulded, } \\
\text { Posted } \\
\text { non-moulded }\end{array}$ & Shoe & $\begin{array}{l}\text { Heel counter } \\
\text { removed }\end{array}$ \\
\hline $\begin{array}{l}\text { Eng and } \\
\text { Pierrynowski }{ }^{38}\end{array}$ & $\begin{array}{l}\text { Walking } \\
\text { and jogging }\end{array}$ & $10 \mathrm{~F}$ & 3 & $\begin{array}{l}\text { See } \\
\text { comments }\end{array}$ & Kinematic & $\begin{array}{l}\text { Flat Spenco insole } \\
\text { postedmedially in } \\
\text { rearfoot and forefoot } \\
\text { with } \\
\text { rubber wedges }\end{array}$ & $\begin{array}{l}\text { Posted } \\
\text { non-moulded }\end{array}$ & Shoe & $\begin{array}{l}\text { Participants } \\
\text { had previously } \\
\text { been prescribed } \\
\text { orthoses by the } \\
\text { same physical } \\
\text { therapist and } \\
\text { physician, } \\
\text { time period not } \\
\text { specified }\end{array}$ \\
\hline MacLean et $a /^{36}$ & Jogging & $12 \mathrm{~F}$ & 2 & Not stated & $\begin{array}{l}\text { Kinematic, } \\
\text { shock } \\
\text { attenuation }\end{array}$ & $\begin{array}{l}\text { Semirigid thermoplastic } \\
\text { functional foot orthosis } \\
\text { intrinsically posted to } \\
\text { calcaneal vertical and } \\
\text { inverted an addition } \\
5^{\circ} \text {. Featured added } \\
\text { EVA rearfoot stabiliser } \\
\text { and EVA top cover }\end{array}$ & $\begin{array}{l}\text { Posted } \\
\text { moulded } \\
\text { (inverted) }\end{array}$ & Shoe & $\begin{array}{l}\text { Measures taken } \\
\text { initially then } \\
\text { post 6-weeks of } \\
\text { wearing orthosis }\end{array}$ \\
\hline MacLean et $a /^{37}$ & Jogging & $15 \mathrm{~F}$ & 1 & 0 & Kinematic & $\begin{array}{l}\text { Cast to calcaneal } \\
\text { vertical and intrinsically } \\
\text { posted an additional } \\
5^{\circ} \text {. Extrinsic rearfoot post } \\
\text { and EVA cushioning } \\
\text { top cover }\end{array}$ & $\begin{array}{l}\text { Posted } \\
\text { moulded }\end{array}$ & Shoe & $\begin{array}{l}\text { Authors state } \\
\text { effect sizes } \\
\text { (ES) but do not } \\
\text { provide enough } \\
\text { data to calculate } \\
\text { mean difference } \\
\text { and } 95 \% \mathrm{Cl}\end{array}$ \\
\hline McCulloch et a/ & $\begin{array}{l}\text { Walking } \\
\text { at } 2 \text { speeds }\end{array}$ & $\begin{array}{l}10 \\
(5 \mathrm{M}, 5 \mathrm{~F})\end{array}$ & 3 & $\begin{array}{l}\text { See } \\
\text { comments }\end{array}$ & Kinematic & $\begin{array}{l}\text { Rigid and semirigid } \\
\text { posted to correct } \\
\text { "biomechanical } \\
\text { dysfunction" }\end{array}$ & $\begin{array}{l}\text { Posted } \\
\text { moulded }\end{array}$ & Shoe & $\begin{array}{l}\text { Reported as } \\
\text { "maximum } \\
\text { pronation." } \\
\text { However, } \\
\text { methodology } \\
\text { describes rear- } \\
\text { foot eversion }\end{array}$ \\
\hline Miller et a/42 & Walking & $\begin{array}{l}25 \\
(13 \mathrm{M}, 12 \mathrm{~F})\end{array}$ & 1 & Not stated & $\begin{array}{l}\text { Shock } \\
\text { attenuation }\end{array}$ & $\begin{array}{l}\text { Custom plastic } \\
\text { polymer orthoses } \\
\text { with medial firm } \\
\text { heel post }\end{array}$ & $\begin{array}{l}\text { Posted } \\
\text { moulded }\end{array}$ & Shoe & $\begin{array}{l}\text { Not enough } \\
\text { data to } \\
\text { calculated mean } \\
\text { differences and } \\
95 \% \mathrm{Cl}\end{array}$ \\
\hline Mündermann et $a l^{30}$ & Jogging & $\begin{array}{l}21 \\
(9 \mathrm{M}, 12 \mathrm{~F})\end{array}$ & 1 & 0 & $\begin{array}{l}\text { Kinematic, } \\
\text { shock } \\
\text { attenuation }\end{array}$ & $\begin{array}{l}\text { (a) EVA bottom layer } \\
\text { with extrinsic } 6 \mathrm{~mm} \\
\text { rearfoot and forefoot } \\
\text { post; (b) neutral } \\
\text { polypropylene shell; } \\
\text { (c) polypropylene shell } \\
\text { with extrinsic EVA } 6 \mathrm{~mm}\end{array}$ & $\begin{array}{l}\text { Posted } \\
\text { non-moulded, } \\
\text { non-posted } \\
\text { moulded, } \\
\text { posted } \\
\text { moulded }\end{array}$ & $\begin{array}{l}\text { Flat EVA } \\
\text { insert in } \\
\text { running } \\
\text { sandal }\end{array}$ & $\begin{array}{l}\text { Ran for } 2 \text { weeks } \\
\text { in running } \\
\text { sandal before } \\
\text { data collection }\end{array}$ \\
\hline Mündermann et al46 & Jogging & $\begin{array}{l}20 \\
(9 \mathrm{M}, 12 \mathrm{~F})\end{array}$ & 1 & Not stated & $\begin{array}{l}\text { Neuromotor } \\
\text { control }\end{array}$ & $\begin{array}{l}\text { (a) Top layer consisted of } \\
\text { 3-mm Spenco. Bottom } \\
\text { layer consisted of } \\
\text { full-length 6-mm } \\
\text { EVA wedge; } \\
\text { (b) custom polypropylene } \\
\text { shell with no extrinsic } \\
\text { posting; } \\
\text { (c) custom polypropylene } \\
\text { shell with 6-mm extrinsic } \\
\text { EVA post added to medial } \\
\text { rearfoot and } \\
\text { forefoot areas }\end{array}$ & $\begin{array}{l}\text { Posted } \\
\text { non-moulded, } \\
\text { non-posted } \\
\text { moulded, } \\
\text { posted } \\
\text { moulded }\end{array}$ & $\begin{array}{l}\text { Flat EVA } \\
\text { insert in } \\
\text { running } \\
\text { sandal }\end{array}$ & $\begin{array}{l}\text { Ran for } 2 \text { weeks } \\
\text { in running } \\
\text { sandal before } \\
\text { data collection }\end{array}$ \\
\hline Murley and Bird 47 & Walking & $\begin{array}{l}15 \\
(7 \mathrm{M}, 10 \mathrm{~F})\end{array}$ & 1 & Not stated & $\begin{array}{l}\text { Neuromotor } \\
\text { control }\end{array}$ & $\begin{array}{l}\text { Custom-made rigid with } \\
15^{\circ} \text { post }\end{array}$ & Posted moulded & Shoe & $\begin{array}{l}\text { Orthosis worn } \\
\text { for } 4 \text { weeks } \\
\text { before data } \\
\text { collection }\end{array}$ \\
\hline
\end{tabular}


Table 1 Continued

\begin{tabular}{|c|c|c|c|c|c|c|c|c|c|}
\hline Author & Activity & $\begin{array}{l}\text { N-total } \\
\text { (sex) }\end{array}$ & $\begin{array}{l}\text { Injury } \\
\text { history }^{*}\end{array}$ & $\begin{array}{l}\text { Previous } \\
\text { orthosis } \\
\text { experience } \\
\text { (mo) }\end{array}$ & Paradigm & Intervention & $\begin{array}{l}\text { Review } \\
\text { category }\end{array}$ & Control & Comments \\
\hline $\begin{array}{l}\text { Nawoczenski } \\
\text { and Ludewig }\end{array}$ & Jogging & $\begin{array}{l}12 \\
(6 \mathrm{M}, 6 \mathrm{~F})\end{array}$ & 3 & 0 & $\begin{array}{l}\text { Neuromotor } \\
\text { control }\end{array}$ & $\begin{array}{l}\text { Custom semirigid } \\
\text { polypropylene with } \\
\text { extrinsic rearfoot and } \\
\text { intrinsic forefoot post }\end{array}$ & $\begin{array}{l}\text { Posted } \\
\text { moulded }\end{array}$ & $\begin{array}{l}\text { Running } \\
\text { sandal }\end{array}$ & $\begin{array}{l}\text { Orthosis worn for } \\
3-4 \text { weeks before } \\
\text { data collection. } \\
\text { Authors do not } \\
\text { provide sufficient } \\
\text { data to calculate } \\
\text { ES. }\end{array}$ \\
\hline Nester et a $/ 40$ & 108 steps/min & $\begin{array}{l}15 \\
(8 \mathrm{M}, 7 \mathrm{~F})\end{array}$ & 1 & Not stated & $\begin{array}{l}\text { Kinematic, } \\
\text { shock } \\
\text { attenuation }\end{array}$ & $\begin{array}{l}\text { High-density EVA } \\
\text { with medium density } \\
10^{\circ} \text { post placed } \\
\text { medially laterally }\end{array}$ & $\begin{array}{l}\text { Posted } \\
\text { non-moulded }\end{array}$ & Shoe & $\begin{array}{l}\text { Data presented as } \\
\text { graphs only }\end{array}$ \\
\hline Nigg et $a /^{31}$ & Jogging & $15 \mathrm{M}$ & 1 & 0 & Kinematic & $\begin{array}{l}\text { Prefabricated rigid EVA } \\
\text { with } 4.5 \text {-mm medial } \\
\text { or lateral posts: } \\
\text { (a) full-length medial; } \\
\text { (b) full-length lateral; } \\
\text { (c) } 0.5 \text { length medial; } \\
\text { (d) } 0.5 \text { length lateral }\end{array}$ & $\begin{array}{l}\text { Posted } \\
\text { non-moulded }\end{array}$ & $\begin{array}{l}\text { Manufacturer's } \\
\text { insert } \\
\text { in shoe }\end{array}$ & $\begin{array}{l}\text { Insufficient data } \\
\text { to calculate ES }\end{array}$ \\
\hline Nigg et $a /^{34}$ & Jogging & $12 \mathrm{M}$ & 1 & 0 & Kinematic & $\begin{array}{l}\text { Bilayer orthoses } \\
\text { (moulding not specified) } \\
\text { made from polyurethane } \\
\text { uppers and } \\
\text { polyethylene or } \\
\text { EVA lower layer: } \\
\text { (a) Medium upper } \\
\text { (Shore C65), soft } \\
\text { EVA lower (shore C75); } \\
\text { (b) soft upper } \\
\text { (Shore C50), soft } \\
\text { polyethylene } \\
\text { lower (Shore C78); } \\
\text { (c) soft upper } \\
\text { (Shore C50), hard lower } \\
\text { (Shore C84); } \\
\text { (d) hard upper } \\
\text { (Shore C70), } \\
\text { soft polyethylene lower } \\
\text { (Shore C78); (e) hard } \\
\text { upper (Shore C70), } \\
\text { hard lower } \\
\text { (Shore C84) }\end{array}$ & Density & Shoe & $\begin{array}{l}\text { Heel counter } \\
\text { removed. Not } \\
\text { enough data pro- } \\
\text { vided to calculate } \\
\text { mean difference } \\
\text { or } \mathrm{Cl}\end{array}$ \\
\hline Nigg et $a^{43}$ & Jogging & $16 \mathrm{M}$ & 1 & Not stated & $\begin{array}{l}\text { Shock } \\
\text { attenuation }\end{array}$ & $\begin{array}{l}\text { Commercially available } \\
\text { viscoelastics orthoses } \\
\text { with Shore values: } \\
\text { (a) } 26 \text { (+stabiliser); } \\
\text { (b) } 28 \text { (+stabiliser); } \\
\text { (c) } 29 \text { (+stabiliser); } \\
\text { (d) } 34 \text { (+stabiliser) }\end{array}$ & Density & $\begin{array}{l}\text { Shoe with } \\
\text { manufacturer's } \\
\text { insert } \pm \text { horse } \\
\text { shoe-shaped } \\
\text { rearfoot } \\
\text { stabiliser }\end{array}$ & $\begin{array}{l}\text { When compared } \\
\text { with shoe with } \\
\text { rearfoot stabiliser, } \\
\text { orthosis condition } \\
\text { also had rearfoot } \\
\text { stabiliser. }\end{array}$ \\
\hline $\begin{array}{l}\text { Stackhouse } \\
\text { et } a^{39}\end{array}$ & Jogging & 15 & 1 & 0 & Kinematic & $\begin{array}{l}\text { Semirigid functional } \\
\text { orthotic devises } \\
\text { fabricated from } \\
\text { suborthelene with } \\
\text { neoprene covers with } \\
6^{\circ} \text { varus posting }\end{array}$ & $\begin{array}{l}\text { Posted } \\
\text { moulded }\end{array}$ & Shoe & $\begin{array}{l}2 \text { weeks } \\
\text { adjustment period } \\
\text { before data col- } \\
\text { lection. Heel } \\
\text { counter removed. } \\
\text { Insufficient data } \\
\text { to calculate Cl } \\
\text { and ES }\end{array}$ \\
\hline Stacoff et a/33 & Walking & $8 \mathrm{M}$ & 3 & 0 & $\begin{array}{l}\text { Kinematic, } \\
\text { neuromotor } \\
\text { control }\end{array}$ & $\begin{array}{l}\text { (a) Bilayer orthosis } \\
\text { (hard lower, soft upper) } \\
\text { posted supporting the } \\
\text { calcaneus at } \\
\text { the sustentaculum } \\
\text { tali; (b) hard density, } \\
\text { supporting the } \\
\text { foot medially and } \\
\text { laterally; (c) designed } \\
\text { with inbuilt } 4 \text { raises } \\
\text { ( } 3 \mathrm{~mm}, 2 \mathrm{~mm} \text { ) at } \\
\text { midfoot, metatarsal } \\
\text { head and toes }\end{array}$ & $\begin{array}{l}\text { Posted } \\
\text { non-moulded, } \\
\text { posted } \\
\text { moulded, } \\
\text { irregular } \\
\text { surface }\end{array}$ & $\begin{array}{l}\text { Running } \\
\text { sandal }\end{array}$ & $\begin{array}{l}\text { Comparisons } \\
\text { made between } \\
\text { orthoses and } \\
\text { first control trials } \\
\text { (start of testing } \\
\text { period) }\end{array}$ \\
\hline
\end{tabular}


Table 1 Continued

\begin{tabular}{|c|c|c|c|c|c|c|c|c|c|}
\hline Author & Activity & $\begin{array}{l}\text { N-total } \\
\text { (sex) }\end{array}$ & $\begin{array}{l}\text { Injury } \\
\text { history* }\end{array}$ & $\begin{array}{l}\text { Previous } \\
\text { orthosis } \\
\text { experience } \\
\text { (mo) }\end{array}$ & Paradigm & Intervention & $\begin{array}{l}\text { Review } \\
\text { category }\end{array}$ & Control & Comments \\
\hline Tomaro and Burdett ${ }^{45}$ & Walking & $\begin{array}{l}10 \\
(3 \mathrm{M}, 7 \mathrm{~F})\end{array}$ & 2 & $>6$ & $\begin{array}{l}\text { Neuromotor } \\
\text { control }\end{array}$ & $\begin{array}{l}\text { Sporthotic devices, } \\
\text { modified to individuals' } \\
\text { subtalar neutral }\end{array}$ & $\begin{array}{l}\text { Posted } \\
\text { moulded }\end{array}$ & Shoe & \\
\hline Williams et $a^{35}$ & Jogging & $\begin{array}{l}11 \\
(5 \mathrm{M}, 6 \mathrm{~F})\end{array}$ & 2 & Chronic & Kinematic & $\begin{array}{l}\text { Custom-made rigid. } \\
\text { Internally posted } \\
\text { to the forefoot } \\
\text { deformity and } \\
\text { externally posted to: } \\
\text { (a) } 4^{\circ} \text {; (b) } 15^{\circ} \text { to } 30^{\circ}\end{array}$ & $\begin{array}{l}\text { Posted } \\
\text { moulded, } \\
\text { posted } \\
\text { moulded } \\
\text { (inverted) }\end{array}$ & Shoe & \\
\hline Zifchock and Davis ${ }^{29}$ & Walking & $\begin{array}{l}37 \\
(17 \mathrm{M}, 20 \mathrm{~F})\end{array}$ & 1 & 0 & Kinematic & $\begin{array}{l}\text { Semigraphite with } \\
\text { vinyl covers: (a) custom: } \\
\text { made from plaster } \\
\text { casts of individuals' foot; } \\
\text { (b) semicustom: } \\
\text { mould-of-best-fit chosen } \\
\text { from range available }\end{array}$ & $\begin{array}{l}\text { Posted } \\
\text { moulded, } \\
\text { posted } \\
\text { moulded }\end{array}$ & Shoe & $\begin{array}{l}\text { Divided into } \\
\text { high and } \\
\text { low arch } \\
\text { based on } \\
\text { arch height } \\
\text { index }\end{array}$ \\
\hline
\end{tabular}

${ }^{*}$ Injury history: 1, no history of injury; 2 , history of injury; 3 , current injury.

EVA, ethylene-vinyl acetate; $M$, male; $F$, female.

involved an orthosis with irregular surface. Nineteen comparisons measured peak rearfoot eversion and 19 measured rearfoot eversion excursion (table 3 ). Results of four papers detailing 11 comparisons did not provide enough data to calculate point estimates of effect.

The effect of orthoses on peak rearfoot eversion seems dependent upon design. For posted non-moulded orthoses, pooled data from two studies of participants with no history of injury revealed a $2.12^{\circ}(95 \%$ CI 0.72 to 3.53$)$ reduction in peak rearfoot eversion during jogging (fig. 2). ${ }^{11,30}$ This finding is in line with the overall tendency for there to be a reduction in peak rearfoot eversion in four non-pooled comparisons during jogging ${ }^{113031}$ and two of the three that studied walking. ${ }^{32}$

For posted moulded orthoses, pooled data from two studies $^{53}$ of currently injured participants revealed a $1.95^{\circ}$ (0.1 to $3.79)$ reduction in peak rearfoot eversion. This finding is in line with two of the three comparisons involving currently injured cohorts which reported moderate (non-significant, eg, CI contained 0) effects in favour of the orthoses. 53

Of non-pooled data, only one comparison reported a statistically significant effect. A posted non-moulded orthosis produced a $2.3^{\circ}$ (0.78 to 3.82$)$ reduction of moderate effect (ES 0.92)..${ }^{30}$ One comparison evaluated the irregular surfaced orthosis (ES 0.28) and another made five comparisons of different material density, where authors did not provide enough information for point estimates of effect, showing small non-systematic effects (table 3). ${ }^{33} 34$

With regard to rearfoot eversion excursion, two comparisons examined the effect of inverted orthoses in cohorts with a history of injury. One study evaluated an inverted orthosis that was posted between $15^{\circ}$ and $30^{\circ}$ (often called a Blake orthosis), ${ }^{35}$ the other inverted the posting an additional $5^{\circ}$ from neutral. ${ }^{36}$ In both studies, the individuals had been wearing their inverted orthoses for a minimum of 6 weeks. Pooled data revealed that the inverted orthoses had no effect $\left(0.21^{\circ}\right.$ (-1.81 to 2.23)) on rearfoot eversion excursion. This finding contrasts that of MacLean et al, ${ }^{37}$ who examined a pragmatic prescription of their custommoulded device ( \pm posting) and qualitatively reported a significant but small (ES 0.32) reduction in rearfoot eversion excursion between $15 \%$ and $50 \%$ of stance. The lack of any substantial effect is in line with all other comparisons regardless of orthosis' design or injury status. Eng and Pierrynowski ${ }^{38}$ reported nearsignificant moderate reductions in the midstance phase of walking (ES 0.82) and contact phase of jogging (ES 0.73) in 10 adolescents with diagnosed patellofemoral pain syndrome.

\section{Tibial internal rotation}

There were 24 comparisons between orthoses and a control involving tibial internal rotation, four made during walking. Eighteen provided enough information to calculate point estimates of effect and confidence intervals (table 4). The majority of comparisons were based on different posting and moulding designs, one used an orthosis with irregular surface and five comparisons were made between a control and orthoses of different densities.

Three sets of pooling were possible. Pooling from two comparisons ${ }^{1130}$ involving participants with no history of injury wearing posted non-moulded orthoses showed a decrease of $1.33^{\circ}(0.13$ to 2.53$)$ in tibial internal rotation when jogging (fig. 2). Likewise, pooled data from two comparisons ${ }^{33} 38$ involving currently injured participants, also wearing posted non-moulded orthoses, found a reduction of $1.66^{\circ}(0.2$ to 3.13$)$ in tibial internal rotation after touchdown during walking gait (fig. 2). Pooling of two comparisons involved cohorts with a history of injury who had worn their inverted posted moulded orthoses for a minimum of 6 weeks. ${ }^{35} 36$ Wearing the inverted orthoses did not change tibial rotation during jogging $\left(2.22^{\circ}\right.$ (-0.83 to 5.26); fig. 2).

From data that were not pooled, Stacoff et al found a posted non-moulded orthosis, consisting of a medial post placed under the calcaneus added to a prefabricated orthosis, decreased tibial internal rotation by $1.59^{\circ}$ (0.21 to 2.97$)$ when jogging. Eng and Pierrynowski ${ }^{38}$ also observed a significant reduction during the touch-down phase of walking gait $\left(1.9^{\circ}\right.$ (0.35 to 3.45$)$ using a similar posted non-moulded device. These finding are of large (ES 1.43) and moderated effect (ES 1.07 ), respectively.

Five qualitative comparisons between orthoses of different densities and a control found that each of the 12 participants responded differently to different orthoses with a tendency towards a reduction in tibial rotation. ${ }^{34}$ 
Table 2 Quality index score

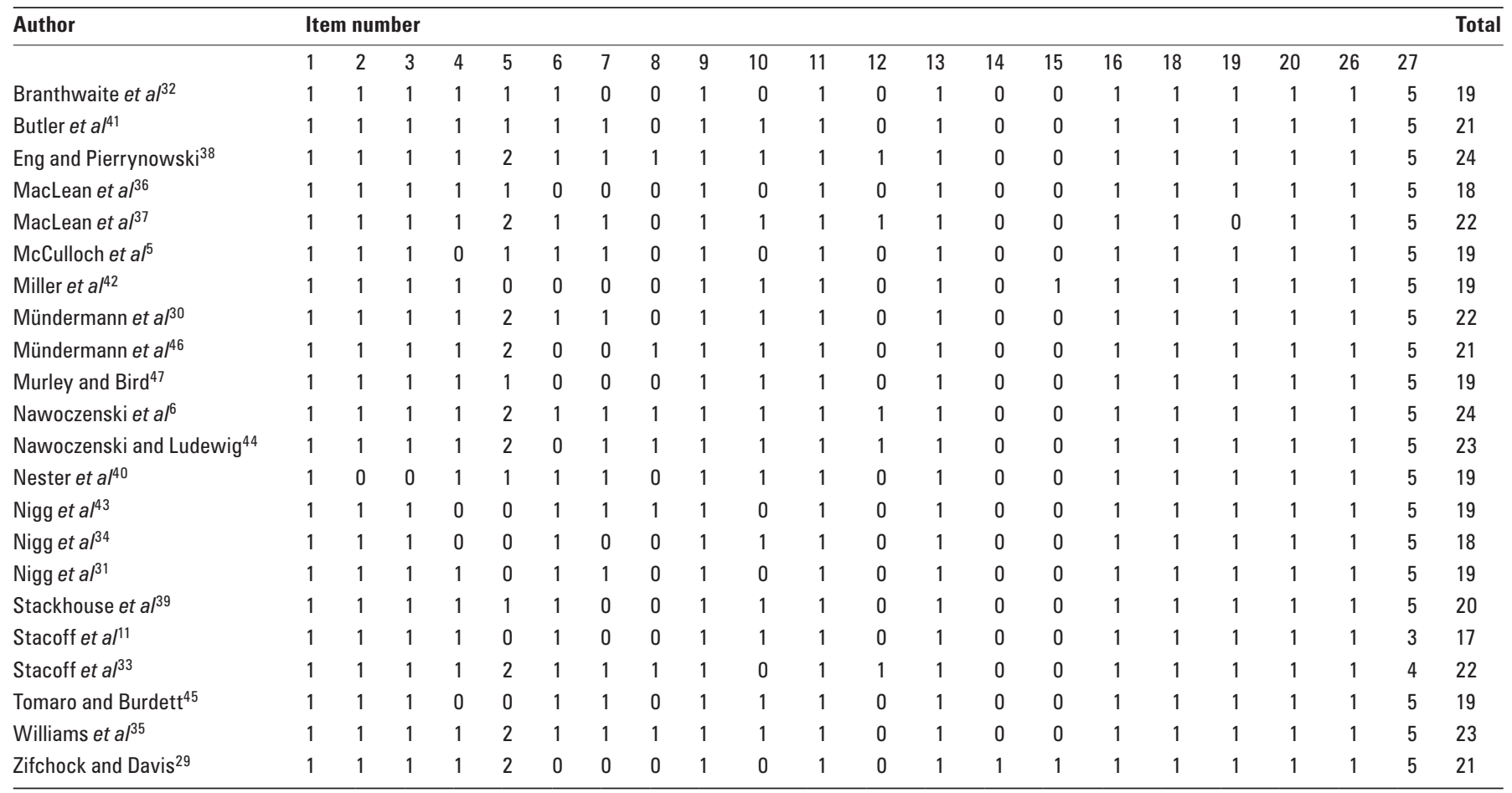

\section{Rearfoot eversion velocity}

We found 19 comparisons over eight studies that examined the effects of orthoses on rearfoot eversion velocity (table 5).

Two comparisons ${ }^{1130}$ that examined the effect of posted non-moulded orthoses on healthy cohorts during jogging were pooled and showed that orthoses had no effect on rearfoot eversion velocity ( $-14.16 \%$ s ( -50.34 to 22.03$)$; fig. 3$)$. This finding is in line with data that were not pooled across all orthoses' designs, 529303339 with the exception of two comparisons. MacLean et $a^{37}$ reported that a posted moulded orthosis cast to calcaneal vertical produced a moderate (ES 0.95) reduction in velocity during the first $15 \%$ of stance phase. A later study reported a tendency for an inverted orthosis to increase velocity (38.66\% (-22.44 to 99.76$)$, ES 0.51$)$ on initial use by individuals with a history of injury. ${ }^{36}$

\section{Maximum ankle inversion moment}

We found 16 comparisons between orthoses and controls measuring maximum ankle inversion moment; in 10 of which, we could generate point estimates of effect and confidence intervals (table 6). No pooling was possible, and results were conflicting between studies where point estimates of effect could and could not be calculated.

Of the 10 comparisons where point estimates of effect could be calculated, only two significant effects were found. In a healthy cohort, a posted non-moulded orthosis significantly reduced maximum ankle inversion moment with moderate effect (6 Nm (1.28 to 10.72), ES 0.77) when jogging. ${ }^{30}$ However, no effect was found using an orthosis of similar design in a currently injured cohort. ${ }^{33}$ An inverted Blake orthosis ${ }^{35}$ had a moderate reducing effect on maximum ankle inversion moment by $0.14 \mathrm{Nm} / \mathrm{kg} / \mathrm{m}(-0.25$ to -0.03 (ES 1.06)).

Of the six comparisons where the point estimate of effects could not be calculated, MacLean et a ${ }^{37}$ and Stackhouse et a ${ }^{\beta 9}$ reported that their posted moulded orthoses produced a significant reduction in ankle inversion moment between $5 \%$ and $75 \%$ of stance phase and, on average, $24 \%$ throughout stance, respectively. Similarly, Nigg et a ${ }^{\beta 1}$ reported that orthoses with either a full length or half length medial post both significantly reduced inversion moment.

\section{Maximum knee external rotation moment}

Twelve comparisons were found, five of which provided enough data to calculate effect and confidence intervals, but pooling was not possible (table 6). ${ }^{30} 36$

Where point estimates of effect and confidence intervals were calculated, orthoses had no effect on maximum knee external rotation moment regardless of design. ${ }^{30} 36$ Six of the remaining comparisons supported these findings. In one comparison between an orthosis with a full-length $4.5-\mathrm{mm}$ medial post and control, the authors reported increased maximum knee external rotation moment $(27.6 \%)$ but did not provide enough data to enable the calculation of confidence intervals. ${ }^{31}$

\section{Between-orthoses comparisons}

Orthoses of differing designs (eg, Cobra, Blake inverted, biplanar, moulded, posted, irregular surface) have been compared. Data pooling was not possible because of the large variability in design features of the compared orthoses.

\section{Rearfoot eversion}

We found 11 comparisons investigating the effects of differing orthoses on peak eversion and four on rearfoot eversion excursion. The majority (seven) of comparisons were between orthoses of different posting and moulding designs. Other comparisons included an irregularly surfaced orthosis, two posted moulded orthoses (one custom-made and the other "mould-of-best-fit") and different posting placement and amount.

With peak rearfoot eversion, a posted moulded orthosis was more effective than a posted non-moulded orthosis $\left(3.3^{\circ}(1.53\right.$ to 5.07$)$, ES 1.83) and the irregular surface orthosis $\left(2.4^{\circ}(0.44\right.$ to 4.36$),$ ES 1.2) in a currently injured cohort. ${ }^{33}$ In participants with no history of injury, the posted non-moulded orthosis was more effective $\left(3.2^{\circ}\right.$ (1.28 to 5.12$)$, ES 1.01). ${ }^{30}$ 
Table 3 Rearfoot eversion results where point estimates of effect and confidence intervals were able to be calculated

\begin{tabular}{|c|c|c|c|c|c|}
\hline Authors & Outcome & Intervention & Comparator & Mean difference $^{\circ}(95 \% \mathrm{CI})$ & $\begin{array}{l}\text { Effect } \\
\text { size } \\
\text { (ES) }\end{array}$ \\
\hline Branthwaite et a/ ${ }^{32}$ & Peak eversion & $\begin{array}{l}\text { Biplanar } \\
\text { Cobra } \\
\text { Biplanar }\end{array}$ & $\begin{array}{l}\text { Control } \\
\text { Control } \\
\text { Cobra }\end{array}$ & $\begin{array}{l}-3.1 \\
-2.1 \\
\text { No difference }\end{array}$ & $\begin{array}{l}0.62 \\
0.46\end{array}$ \\
\hline $\begin{array}{l}\text { Eng and } \\
\text { Pierrynowski }{ }^{38}\end{array}$ & $\begin{array}{l}\text { Eversion } \\
\text { excursion }\end{array}$ & Posted non-moulded & Control & $\begin{array}{l}\text { Walking: contact }-1.8(-5.13 \text { to } 1.53) \\
\text { Midstance }-1.8(-3.73 \text { to } 0.13) \\
\text { Propulsion }-0.4(-2.42 \text { to } 1.62) \\
\text { Jogging: contact }-2.5(-5.49 \text { to } 0.49) \\
\text { Midstance }-0.8(-2.42 \text { to } 0.82) \\
\text { Propulsion }-1.7(-4.15 \text { to } 0.75)\end{array}$ & $\begin{array}{l}0.47 \\
0.82 \\
0.17 \\
0.73 \\
0.43 \\
0.61\end{array}$ \\
\hline MacLean et $a /^{36}$ & $\begin{array}{l}\text { Eversion } \\
\text { excursion }\end{array}$ & Posted moulded (Inverted) & Control & $\begin{array}{l}\text { Initial: } 1.56(-2.05 \text { to } 5.17) \\
\text { After } 6 \text { weeks of wear: } 0.88 \\
(-2.97 \text { to } 4.73)\end{array}$ & $\begin{array}{l}0.35 \\
0.18\end{array}$ \\
\hline MacLean et $a{ }^{\beta 7}$ & $\begin{array}{l}\text { Peak eversion } \\
\text { Eversion } \\
\text { excursion }\end{array}$ & Posted moulded & Control & $\begin{array}{l}\text { Peak eversion: reduction } \\
\text { Decreased calcaneal eversion angle }\end{array}$ & $\begin{array}{l}0.32 \\
0.25\end{array}$ \\
\hline McCulloch et a/ ${ }^{5}$ & Peak eversion & Posted moulded & Control & $\begin{array}{l}\text { Walking } 3.2 \mathrm{~km} / \mathrm{h}:-4.0(-8.7 \text { to } 0.7) \\
\text { Walking } 4.8 \mathrm{~km} / \mathrm{h}:-2.7(-7.29 \text { to } 1.89)\end{array}$ & $\begin{array}{l}0.75 \\
0.52\end{array}$ \\
\hline Mündermann et a/30 & Peak eversion & $\begin{array}{l}\text { Posted non-moulded } \\
\text { Non-posted moulded } \\
\text { Posted moulded } \\
\text { Posted non-moulded } \\
\text { Posted non-moulded } \\
\text { Non-posted moulded }\end{array}$ & $\begin{array}{l}\text { Control } \\
\text { Control } \\
\text { Control } \\
\text { Non-posted moulded } \\
\text { Posted moulded } \\
\text { Posted moulded }\end{array}$ & $\begin{array}{l}-2.3(-3.82 \text { to }-0.78) \\
0.6(-0.85 \text { to } 2.05) \\
0.9(-0.93 \text { to } 2.73) \\
-2.9(-4.47 \text { to }-1.33) \\
-3.2(-5.12 \text { to }-1.28) \\
-0.3(-2.17 \text { to } 1.57)\end{array}$ & $\begin{array}{l}0.92 \\
0.25 \\
0.3 \\
1.11 \\
1.01 \\
0.1\end{array}$ \\
\hline Nigg et $\left.a\right|^{31}$ & $\begin{array}{l}\text { Peak eversion } \\
\text { Eversion } \\
\text { excursion }\end{array}$ & $\begin{array}{l}\text { Full-length medial post } \\
\text { Full-length medial post } \\
\text { Full-length lateral post }\end{array}$ & $\begin{array}{l}\text { Control } \\
\text { Control } \\
\text { Control }\end{array}$ & $\begin{array}{l}-1.5 S D \pm 1.3 \\
-2 S D \pm 1.5 \\
2.1 S D \pm 1.7\end{array}$ & \\
\hline Stacoff et a/33 & Peak eversion & $\begin{array}{l}\text { Posted non-moulded } \\
\text { Posted moulded } \\
\text { Irregular surface } \\
\text { Posted moulded } \\
\text { Posted moulded } \\
\text { Irregular surface }\end{array}$ & $\begin{array}{l}\text { Control } \\
\text { Control } \\
\text { Control } \\
\text { Posted non-moulded } \\
\text { Irregular surface } \\
\text { Posted non-moulded }\end{array}$ & $\begin{array}{l}1.5(-0.43 \text { to } 3.43) \\
-1.8(-3.81 \text { to } 0.21) \\
0.6(-1.51 \text { to } 2.71) \\
-3.3(-5.07 \text { to }-1.53) \\
-2.4(-4.36 \text { to }-0.44) \\
-0.9(-2.77 \text { to } 0.97)\end{array}$ & $\begin{array}{l}0.76 \\
0.88 \\
0.28 \\
1.83 \\
1.2 \\
0.47\end{array}$ \\
\hline Stacoff et al ${ }^{11}$ & $\begin{array}{l}\text { Peak eversion } \\
\text { Eversion } \\
\text { excursion }\end{array}$ & $\begin{array}{l}\text { Posted non-moulded (Anterior) } \\
\text { Posted non-moulded (Posterior) } \\
\text { Posted non-moulded (Posterior) } \\
\text { Posted non-moulded (Anterior) } \\
\text { Posted non-moulded (Posterior) } \\
\text { Posted non-moulded (Anterior) }\end{array}$ & $\begin{array}{l}\text { Control } \\
\text { Control } \\
\text { Posted non-moulded (Anterior) } \\
\text { Control } \\
\text { Control } \\
\text { Posted non-moulded (Posterior) }\end{array}$ & $\begin{array}{l}-0.83(-4.34 \text { to } 2.68) \\
-1.03(-4.79 \text { to } 2.73) \\
-0.20(-4.01 \text { to } 3.61) \\
-0.26(-3.64 \text { to } 3.12) \\
-0.34(-3.63 \text { to } 2.95) \\
-0.08(-3.44 \text { to } 3.28)\end{array}$ & $\begin{array}{l}0.29 \\
0.34 \\
0.07 \\
0.1 \\
0.13 \\
0.03\end{array}$ \\
\hline Williams et $a l^{35}$ & $\begin{array}{l}\text { Peak eversion } \\
\text { Eversion } \\
\text { excursion }\end{array}$ & $\begin{array}{l}4^{\circ} \text { posted moulded } \\
\text { Inverted posted moulded } \\
\text { Inverted posted moulded } \\
4^{\circ} \text { posted moulded } \\
\text { Inverted posted moulded } \\
4^{\circ} \text { posted moulded }\end{array}$ & $\begin{array}{l}\text { Control } \\
\text { Control } \\
4^{\circ} \text { posted moulded } \\
\text { Control } \\
\text { Control } \\
\text { Inverted posted moulded }\end{array}$ & $\begin{array}{l}1.59(-1.66 \text { to } 4.84) \\
1.2(-1.87 \text { to } 4.27) \\
-0.39(-3.4 \text { to } 2.62) \\
-0.82(-3.42 \text { to } 1.78) \\
-0.05(-2.42 \text { to } 2.32) \\
-0.77(-3.37 \text { to } 1.83)\end{array}$ & $\begin{array}{l}0.41 \\
0.3 \\
0.11 \\
0.29 \\
0.02 \\
0.25\end{array}$ \\
\hline Zifchock and Davis ${ }^{25}$ & $\begin{array}{l}\text { Peak eversion } \\
\text { Eversion } \\
\text { excursion }\end{array}$ & $\begin{array}{l}\text { Posted moulded (semicustom) } \\
\text { Posted moulded (custom) } \\
\text { Posted moulded (semicustom) } \\
\text { Posted moulded (semicustom) } \\
\text { Posted moulded (custom) } \\
\text { Posted moulded (custom) } \\
\text { Posted moulded (semicustom) }\end{array}$ & $\begin{array}{l}\text { Control } \\
\text { Control } \\
\text { Posted moulded (custom) } \\
\text { Control } \\
\text { Control } \\
\text { Posted moulded (semicustom) } \\
\text { Posted moulded (custom) }\end{array}$ & $\begin{array}{l}\text { Low arch: } 0.06(-1.45 \text { to } 1.58) \\
\text { High arch: }-0.03(-2.02 \text { to } 1.95) \\
\text { Low arch: } 1.13(-1.46 \text { to } 3.37) \\
\text { High arch: } 0.28(-1.88 \text { to } 2.45) \\
\text { Low arch: }-1.07(-3.06 \text { to } 1.46) \\
\text { High arch: }-0.32(-2.09 \text { to } 1.46) \\
\text { Low arch: }-0.92 \text { (-2.46 to } 0.61) \\
\text { High arch: }-0.84 \text { (-2.86 to } 1.18) \\
\text { Low arch: }-1.13(-2.70 \text { to } 0.44) \\
\text { High arch: }-0.76(-2.76 \text { to } 1.23) \\
\text { Low arch: }-0.2(-1.4 \text { to } 1.0) \\
\text { High arch: }-0.08(-1.92 \text { to } 1.76)\end{array}$ & $\begin{array}{l}0.03 \\
0.01 \\
0.29 \\
0.08 \\
0.28 \\
0.11 \\
0.39 \\
0.26 \\
0.47 \\
0.24 \\
0.11 \\
0.03\end{array}$ \\
\hline
\end{tabular}

No orthosis design, degree or placement of posting seemed to be more effective in influencing excursion.

\section{Tibial internal rotation}

Of the eight between-orthosis comparisons (table 4), only one reported a moderate non-significant effect (ES 1.07). A reduction of $1.05^{\circ}(-0.16$ to 2.26$)$ in tibial internal rotation occurred when a non-moulded orthosis with a medial post placed under the calcaneus was compared with a post placed under the medial arch. ${ }^{11}$ It would seem that no design feature is more effective at reducing tibial internal rotation.
Rearfoot eversion velocity

We found seven between-orthosis comparisons for rearfoot eversion velocity. Six involved different posting and moulding features 203032 and the other compared a posterior post with an anterior post (table 5). ${ }^{11}$

Jogging in a posted non-moulded orthosis was found to have a moderate effect over posted moulded orthoses (91.5\% (7.98 to 175.02), ES 0.66) and non-posted moulded orthoses (ES 0.6) when participants had no history of injury. ${ }^{30}$ No other significant results were found. 
Table 4 Tibial internal rotation comparisons of studies where point estimates of effect and confidence intervals were able to be calculated

\begin{tabular}{|c|c|c|c|c|}
\hline Authors & Intervention & Comparator & Mean difference $(95 \% \mathrm{Cl})$ & $\begin{array}{l}\text { Effect size } \\
\text { (ES) }\end{array}$ \\
\hline MacLean et a/2008 36 & Posted moulded (Inverted) & Control & $\begin{array}{l}\text { Initial }-1.38 \text { ( }-4.99 \text { to } 2.33 \text { ) } \\
\text { After } 6 \text { weeks of wear }-0.14 \text { ( }-4.48 \text { to } 4.2)\end{array}$ & $\begin{array}{l}0.31 \\
0.03\end{array}$ \\
\hline Nawoczenski et a/ ${ }^{6}$ & $\begin{array}{l}\text { Posted moulded (low rearfoot), } \\
\text { posted moulded (high rearfoot) } \\
\text { Posted moulded (low rearfoot), } \\
\text { posted moulded (high rearfoot) }\end{array}$ & $\begin{array}{l}\text { Control, control } \\
\text { Control, control }\end{array}$ & $\begin{array}{l}\text { Internal rotation with respect to } \\
\text { rearfoot: } 2.0(-4.31 \text { to } 0.31) \text {, } \\
-2.3(-6.26 \text { to } 1.66) \\
\text { Total internal/external rotation: } \\
-1.2(-4.64 \text { to } 2.24),-1.6(-6.34 \text { to } 3.14)\end{array}$ & $\begin{array}{l}0.76,0.37 \\
0.31,0.3\end{array}$ \\
\hline Stacoff et a $/^{11}$ & $\begin{array}{l}\text { Posted non-moulded (anterior) } \\
\text { Posted non-moulded (posterior) } \\
\text { Posted non-moulded (posterior) }\end{array}$ & $\begin{array}{l}\text { Control } \\
\text { Control } \\
\text { Posted non-moulded (anterior) }\end{array}$ & $\begin{array}{l}-0.54(-1.37 \text { to } 0.29) \\
-1.59(-2.97 \text { to }-0.21) \\
-1.05(-2.26 \text { to } 0.16)\end{array}$ & $\begin{array}{l}0.81 \\
1.43 \\
1.07\end{array}$ \\
\hline Williams et $a /^{35}$ & $\begin{array}{l}4^{\circ} \text { posted moulded } \\
\text { Inverted posted moulded } \\
4^{\circ} \text { posted moulded }\end{array}$ & $\begin{array}{l}\text { Control } \\
\text { Control } \\
\text { Inverted oosted moulded }\end{array}$ & $\begin{array}{l}3.33(-1.94 \text { to } 8.6) \\
4.5(-0.23 \text { to } 8.77) \\
-1.17(-5.55 \text { to } 3.21)\end{array}$ & $\begin{array}{l}0.53 \\
0.88 \\
0.22\end{array}$ \\
\hline
\end{tabular}

Table 5 Rearfoot eversion velocity comparisons for studies where point estimates of effect and confidence intervals were able to be calculated

\begin{tabular}{|c|c|c|c|c|}
\hline Authors & Intervention & Comparator & Mean difference (95\% CI) & $\begin{array}{l}\text { Effect } \\
\text { size (ES) }\end{array}$ \\
\hline Branthwaite et $a /^{32}$ & $\begin{array}{l}\text { Biplanar } \\
\text { Cobra } \\
\text { Biplanar }\end{array}$ & $\begin{array}{l}\text { Control } \\
\text { Control } \\
\text { Cobra }\end{array}$ & $\begin{array}{l}-4(-20.37 \text { to } 12.37) \\
5(-7.55 \text { to } 17.55) \\
-9(-26.4 \text { to } 8.4)\end{array}$ & $\begin{array}{l}0.23 \\
0.35 \\
0.48\end{array}$ \\
\hline MacLean et a/ ${ }^{36}$ & Posted moulded (Inverted) & Control & $\begin{array}{l}\text { Initial: } 38.66 \text { ( }-22.44 \text { to } 99.76) \\
\text { After } 6 \text { weeks of wear: } 37.58(-43.9 \text { to } 119.06)\end{array}$ & $\begin{array}{l}0.51 \\
0.37\end{array}$ \\
\hline McCulloch et a/ ${ }^{5}$ & Posted moulded & Control & $\begin{array}{l}\text { Rate of pronation first } 10 \% \text { stance } \\
\text { walking } 3.2 \mathrm{~km} / \mathrm{h}: 4.5(-13.68 \text { to } 22.68) \text {, } \\
\text { walking } 4.8 \mathrm{~km} / \mathrm{h}: 1.5(-21.17 \text { to } 24.17) \\
\text { Rate of pronation second } 10 \% \text { stance } \\
\text { walking } 3.2 \mathrm{~km} / \mathrm{h}:-6.2(-23.94 \text { to } 11.54) \text {, } \\
\text { walking } 4.8 \mathrm{~km} / \mathrm{h}: 1.1(-17.22 \text { to } 19.42)\end{array}$ & $\begin{array}{l}0.22 \\
0.06 \\
0.31 \\
0.05\end{array}$ \\
\hline Mündermann et a/30 & $\begin{array}{l}\text { Posted non-moulded } \\
\text { Non-moulded posted } \\
\text { Posted moulded } \\
\text { Posted non-moulded } \\
\text { Posted non-moulded } \\
\text { Non-posted moulded }\end{array}$ & $\begin{array}{l}\text { Control } \\
\text { Control } \\
\text { Control } \\
\text { Non-posted moulded } \\
\text { Posted moulded } \\
\text { Posted moulded }\end{array}$ & $\begin{array}{l}-71.8(-159.78 \text { to } 16.18) \\
12.1(-78.74 \text { to } 102.94) \\
19.7(-70.01 \text { to } 109.41) \\
-83.9(-168.63 \text { to } 0.83) \\
-91.5(-175.02 \text { to }-7.98) \\
-7.6(-94.13 \text { to } 78.93)\end{array}$ & $\begin{array}{l}0.49 \\
0.08 \\
0.13 \\
0.6 \\
0.66 \\
0.05\end{array}$ \\
\hline Stackhouse et a/ ${ }^{39}$ & Posted moulded & Control & -7.85 (not significant) & \\
\hline Stacoff et al ${ }^{11}$ & $\begin{array}{l}\text { Posted non-moulded (anterior) } \\
\text { Posted non-moulded (posterior) } \\
\text { Posted non-moulded (posterior) }\end{array}$ & $\begin{array}{l}\text { Control } \\
\text { Control } \\
\text { Posted non-moulded (Anterior) }\end{array}$ & $\begin{array}{l}5.0(-35.61 \text { to } 45.61) \\
-2.42(-42.12 \text { to } 37.28) \\
-7.42(-45.51 \text { to } 30.67)\end{array}$ & $\begin{array}{l}0.15 \\
0.08 \\
0.24\end{array}$ \\
\hline Zifchock and Davis $2008^{25}$ & $\begin{array}{l}\text { Posted moulded (semicustom) } \\
\text { Posted moulded (custom) } \\
\text { Posted moulded (custom) } \\
\text { Posted moulded (custom) }\end{array}$ & $\begin{array}{l}\text { Control } \\
\text { Control } \\
\text { Posted moulded (semicustom) } \\
\text { Posted moulded (semicustom) }\end{array}$ & $\begin{array}{l}\text { Low arch: }-10.87(-41.37 \text { to } 19.63) \\
\text { High arch: }-14.32(-50.92 \text { to } 22.28) \\
\text { Low arch: }-14.14(-44.87 \text { to } 16.58) \\
\text { High arch: }-20.51(-56.08 \text { to } 15.06) \text {, } \\
-3.27 \text { (-33.87 to } 27.32) \text {, } \\
-6.19 \text { (-34.14 to } 21.76)\end{array}$ & $\begin{array}{l}0.23 \\
0.25 \\
0.3 \\
0.37 \\
0.07 \\
0.14\end{array}$ \\
\hline
\end{tabular}

\section{Maximum ankle inversion moment}

Of the seven between-orthoses comparisons for maximum ankle inversion moment, there were six between orthoses of different moulding and posting designs and another between a moulded-inverted orthosis to a moulded orthosis with a $4^{\circ}$ post (table 6). The latter showed a small tendency for the inverted posted moulded orthosis to reduce maximum ankle inversion by $0.07 \mathrm{Nm} / \mathrm{kg} / \mathrm{m}$ (-0.04 to 0.18 ) over the comparator (ES 0.58). ${ }^{35}$ 
Table 6 Kinematic outcomes for comparisons where point estimates of effect and confidence intervals were able to be calculated

\begin{tabular}{|c|c|c|c|c|c|}
\hline Authors & Outcome & Intervention & Comparator & Mean difference $(95 \% \mathrm{CI})$ & $\begin{array}{l}\text { Effect } \\
\text { size (ES) }\end{array}$ \\
\hline MacLean et a/36 & $\begin{array}{l}\text { Maximum ankle inversion } \\
\text { moment } \\
\text { Maximum knee } \\
\text { external rotation moment }\end{array}$ & $\begin{array}{l}\text { Posted moulded (Inverted) } \\
\text { Posted moulded (Inverted) }\end{array}$ & $\begin{array}{l}\text { Control } \\
\text { Control }\end{array}$ & $\begin{array}{l}\text { Initial: }-0.05(-0.22 \text { to } 0.12) \text {, } \\
\text { After } 6 \text { weeks of wear: }-0.07(-0.59 \text { to } 0.45) \\
\text { Initial: }-0.04 \text { ( }-0.15 \text { to } 0.07) \text {, } \\
\text { After } 6 \text { weeks of wear: }-0.01(-0.17 \text { to } 0.15)\end{array}$ & $\begin{array}{l}0.23,0.22 \\
0.3,0.05\end{array}$ \\
\hline Mündermann et $a l^{30}$ & $\begin{array}{l}\text { Maximum ankle inversion } \\
\text { moment } \\
\text { Maximum knee } \\
\text { external rotation moment }\end{array}$ & $\begin{array}{l}\text { Posted non-moulded } \\
\text { Non-posted moulded } \\
\text { Posted moulded } \\
\text { Posted non-moulded } \\
\text { Posted non-moulded } \\
\text { Posted moulded } \\
\text { Posted non-moulded } \\
\text { Non-moulded posted } \\
\text { Posted moulded } \\
\text { Posted non-moulded } \\
\text { Posted non-moulded } \\
\text { Non-posted moulded }\end{array}$ & $\begin{array}{l}\text { Control } \\
\text { Control } \\
\text { Control } \\
\text { Non-posted moulded } \\
\text { Moulded-posted } \\
\text { Non-posted moulded } \\
\text { Control } \\
\text { Control } \\
\text { Control } \\
\text { Posted non-moulded } \\
\text { Posted moulded } \\
\text { Posted moulded }\end{array}$ & 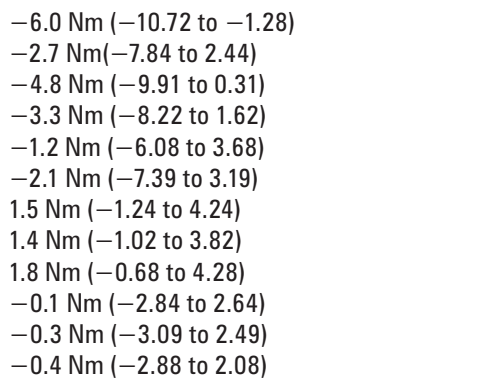 & $\begin{array}{l}0.77 \\
0.32 \\
0.57 \\
0.41 \\
0.15 \\
0.24 \\
0.33 \\
0.35 \\
0.44 \\
0.02 \\
0.06 \\
0.1\end{array}$ \\
\hline Stacoff et $a /^{33}$ & $\begin{array}{l}\text { Maximum ankle inversion } \\
\text { moment }\end{array}$ & $\begin{array}{l}\text { Posted non-moulded } \\
\text { Posted moulded } \\
\text { Irregular surface } \\
\text { Posted non-moulded } \\
\text { Posted non-moulded } \\
\text { Irregular surface }\end{array}$ & $\begin{array}{l}\text { Control } \\
\text { Control } \\
\text { Control } \\
\text { Posted moulded } \\
\text { Irregular surface } \\
\text { Posted moulded }\end{array}$ & $\begin{array}{l}-0.50 \mathrm{Nm}(-11.29 \text { to } 10.29) \\
1.4 \mathrm{Nm}(-9.89 \text { to } 12.69) \\
0.6 \mathrm{Nm}(-10.46 \text { to } 11.66) \\
-1.9 \mathrm{Nm}(-12.06 \text { to } 8.26) \\
-1.1 \mathrm{Nm}(-11.0 \text { to } 8.8) \\
-0.8 \mathrm{Nm}(-11.24 \text { to } 9.64)\end{array}$ & $\begin{array}{l}0.05 \\
0.12 \\
0.05 \\
0.18 \\
0.11 \\
0.07\end{array}$ \\
\hline Williams et $a /^{35}$ & $\begin{array}{l}\text { Maximum ankle inversion } \\
\text { moment }\end{array}$ & $\begin{array}{l}4^{\circ} \text { posted moulded Posted } \\
\text { moulded (Inverted) } \\
\text { Posted moulded } \\
\text { (converted) }\end{array}$ & $\begin{array}{l}\text { Control } \\
\text { Control } \\
4^{\circ} \text { posted moulded }\end{array}$ & $\begin{array}{l}-0.06 \mathrm{Nm} / \mathrm{kg} / \mathrm{m}(-0.20 \text { to } 0.06) \\
-0.14 \mathrm{Nm} / \mathrm{kg} / \mathrm{m}(-0.25 \text { to }-0.03) \\
-0.07 \mathrm{Nm} / \mathrm{kg} / \mathrm{m}(-0.18 \text { to } 0.04)\end{array}$ & $\begin{array}{l}0.41 \\
1.06 \\
0.58\end{array}$ \\
\hline
\end{tabular}

\section{Peak rearfoot eversion}

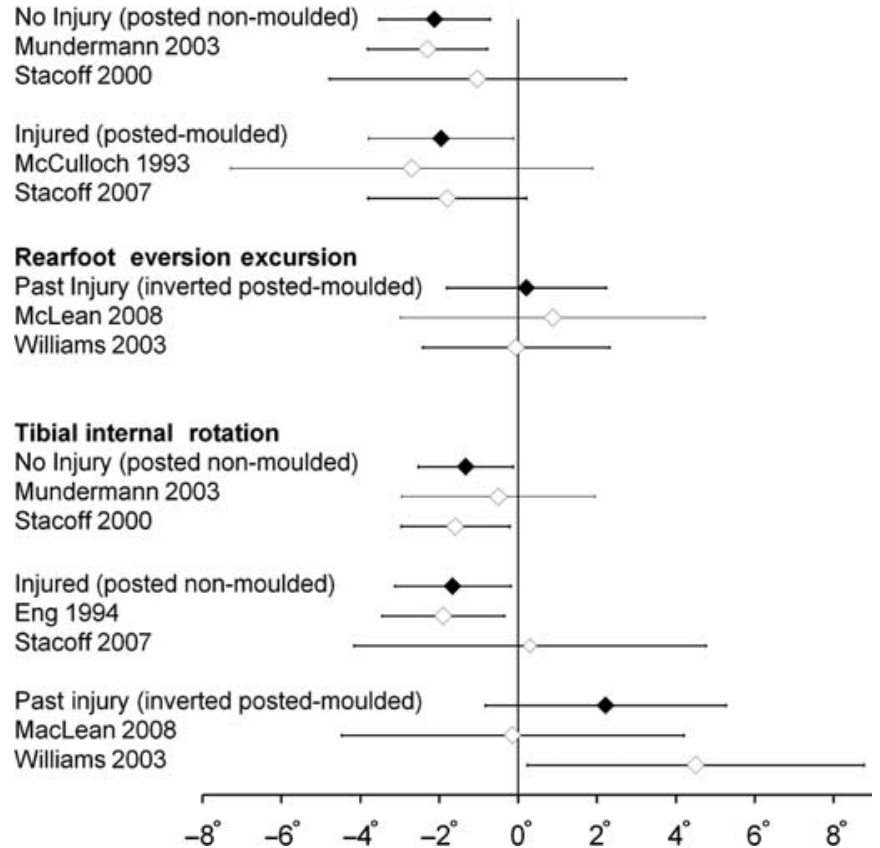

Figure 2 Forest plot of data pooling for rearfoot eversion and tibial internal rotation. Filled diamonds represent pooled data.

\section{Maximum knee external rotation moment}

We found four between-orthoses comparisons in the literature regarding maximum knee external rotation moment (table 6), all equivocal. ${ }^{30} 40$

\section{Shock attenuation}

The search strategy yielded 42 comparisons, from six studies on shock attenuation. ${ }^{303640-43}$ Orthoses were compared on the basis of density (22), with or without rearfoot stabilisation, or
Rearfoot eversion velocity

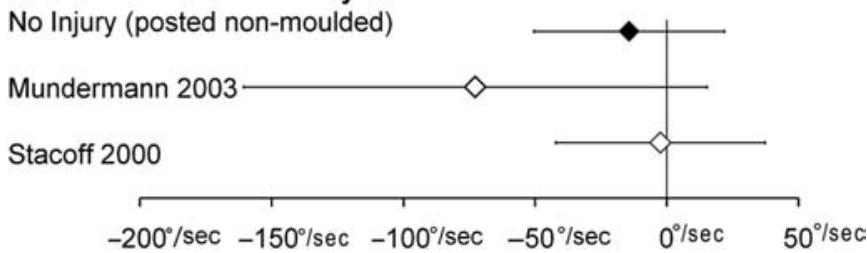

Figure 3 Forest plot of data pooling for rearfoot eversion velocity. Filled diamonds represent pooled data.

variations of posting and moulding (20). The outcome measures consisted of tibial acceleration (3), loading rate (19), vertical impact force (16) and vertical ground reaction force (4) (table 7).

Tibial acceleration

Three comparisons involving two densities and a control showed no differential effects on tibial acceleration (ES $0.01-0.16){ }^{41}$

\section{Loading rate}

Comparisons were divided into those investigating density (11), ${ }^{32} 4043$ and those investigating design (7). ${ }^{30} 36$ The former did not differentiate on loading rate, ${ }^{43}$ regardless of the presence of rearfoot stabilisation. When orthoses differed in design, non-posted moulded and posted moulded both had significant moderate effects over the control (ES 0.69 and 0.95, respectively) and a posted non-moulded orthosis (ES 0.76 and 1.01, respectively). ${ }^{30}$ These results were found in participants without injury. A reduction in loading rate brought about by a posted moulded orthosis was also reported in participants with a history of injury (-19.56 BW/s (-37.24 to -1.88$))$, but only after 6 weeks. ${ }^{36}$

Vertical impact force

We found three studies of vertical impact force with $16 \mathrm{com}$ parisons of orthoses differing in density and design. ${ }^{30} 3643$ 
Table 7 Shock attenuation paradigm comparisons when point estimates of effect and confidence intervals were able to be calculated

\begin{tabular}{|c|c|c|c|c|c|}
\hline Authors & Outcome & Intervention & Comparator & Mean difference $(95 \% \mathrm{CI})$ & $\begin{array}{l}\text { Effect size } \\
\text { (ES) }\end{array}$ \\
\hline Butler et $a l^{41}$ & $\begin{array}{l}\text { Tibial acceleration }(\mathrm{g}) \\
\text { Loading rate }(\mathrm{BW} / \mathrm{s})\end{array}$ & $\begin{array}{l}\text { Posted moulded (rigid) } \\
\text { Posted moulded (Soft) } \\
\text { Posted moulded (rigid) } \\
\text { Posted moulded (rigid) } \\
\text { Posted moulded (Soft) } \\
\text { Posted moulded (rigid) }\end{array}$ & $\begin{array}{l}\text { Control } \\
\text { Control } \\
\text { Posted moulded (soft) } \\
\text { Control } \\
\text { Control } \\
\text { Posted moulded (soft) }\end{array}$ & $\begin{array}{l}-0.2(-2.35 \text { to } 1.95) \\
0.3(-1.92 \text { to } 2.52) \\
-0.5(-2.72 \text { to } 1.72) \\
-6(-16.19 \text { to } 4.19) \\
-3.4(-12.55 \text { to } 5.75) \\
-2.6(-14.37 \text { to } 9.17)\end{array}$ & $\begin{array}{l}0.07 \\
0.1 \\
0.16 \\
0.47 \\
0.27 \\
0.16\end{array}$ \\
\hline MacLean et a/ ${ }^{36}$ & $\begin{array}{l}\text { Impact peak (BW) } \\
\text { Maximum loading rate }(\mathrm{BW} / \mathrm{s})\end{array}$ & $\begin{array}{l}\text { Posted moulded } \\
\text { Posted moulded }\end{array}$ & $\begin{array}{l}\text { Control } \\
\text { Control }\end{array}$ & $\begin{array}{l}\text { Initial: }-0.11(-0.28 \text { to } 0.06) \text {, } \\
6 \text { weeks: } 0.1(-1.17 \text { to } 0.97) \\
\text { Initial: }-12.04(-33.51 \text { to } 9.43) \\
6 \text { weeks: }-19.56(-37.24 \text { to }-1.88)\end{array}$ & $\begin{array}{l}0.52,0.42 \\
0.43,0.89\end{array}$ \\
\hline Mündermann et $\left.a\right|^{30}$ & $\begin{array}{l}\text { Vertical impact peak (N) } \\
\text { Maximum loading rate (N/s) }\end{array}$ & $\begin{array}{l}\text { Posted non-moulded } \\
\text { Non-posted moulded } \\
\text { Posted moulded } \\
\text { Non-posted moulded } \\
\text { Posted moulded } \\
\text { Posted moulded } \\
\text { Posted non-moulded } \\
\text { Non-posted moulded } \\
\text { Posted moulded } \\
\text { Non-posted moulded } \\
\text { Posted moulded } \\
\text { Posted moulded }\end{array}$ & $\begin{array}{l}\text { Control } \\
\text { Control } \\
\text { Control } \\
\text { Posted non-moulded } \\
\text { Posted non-moulded } \\
\text { Non-posted moulded } \\
\text { Control } \\
\text { Control } \\
\text { Control } \\
\text { Posted non-moulded } \\
\text { Posted non-moulded } \\
\text { Non-posted moulded }\end{array}$ & $\begin{array}{l}20.3(-137.45 \text { to } 178.05) \\
-98.7(-249.39 \text { to } 51.99) \\
-146.8(-249.9 \text { to } 1.30) \\
-119(-272.92 \text { to } 34.92) \\
-167.1(-318.48 \text { to }-15.72) \\
-48.1(-192.11 \text { to } 95.91) \\
1(-5.96 \text { to } 7.96) \\
-7.7(-14.41 \text { to }-0.99) \\
-10.5(-17.15 \text { to }-3.85) \\
-8.7(-15.66 \text { to }-1.74) \\
-11.5(-18.4 \text { to }-4.6) \\
-2.8(-9.45 \text { to } 3.85)\end{array}$ & $\begin{array}{l}0.04 \\
0.4 \\
0.6 \\
0.47 \\
0.67 \\
0.2 \\
0.09 \\
0.69 \\
0.95 \\
0.76 \\
1.01 \\
0.25\end{array}$ \\
\hline Nigg et al43 & $\begin{array}{l}\text { Vertical impact force }(\mathrm{N}) \\
\text { Loading rate }(\mathrm{kN} / \mathrm{s})\end{array}$ & $\begin{array}{l}\text { Shore } 26 \\
\text { Shore } 28 \\
\text { Shore } 29 \\
\text { Shore } 34 \\
\text { Shore } 26 \text { + stabiliser } \\
\text { Shore } 28+\text { stabiliser } \\
\text { Shore } 29+\text { stabiliser } \\
\text { Shore } 34 \text { + stabiliser } \\
\text { Shore } 26 \\
\text { Shore } 28 \\
\text { Shore } 29 \\
\text { Shore } 34 \\
\text { Shore } 26 \text { + stabiliser } \\
\text { Shore } 28 \text { + stabiliser } \\
\text { Shore } 29 \text { + stabiliser } \\
\text { Shore } 34 \text { + stabiliser }\end{array}$ & $\begin{array}{l}\text { Control } \\
\text { Control } \\
\text { Control } \\
\text { Control } \\
\text { Control + stabiliser } \\
\text { Control + stabiliser } \\
\text { Control + stabiliser } \\
\text { Control + stabiliser } \\
\text { Control } \\
\text { Control } \\
\text { Control } \\
\text { Control } \\
\text { Control + stabiliser } \\
\text { Control + stabiliser } \\
\text { Control + stabiliser } \\
\text { Control + stabiliser }\end{array}$ & $\begin{array}{l}-118(-179.88 \text { to } 115.88) \\
-92(-255.62 \text { to } 71.62) \\
-88(-273.76 \text { to } 97.76) \\
-63(-235.31 \text { to } 109.31) \\
-52(-193.06 \text { to } 89.06) \\
-32(-179.88 \text { to } 115.88) \\
-40(-179.99 \text { to } 99.99) \\
-52(-202.6 \text { to } 98.6) \\
-2.92(17.39 \text { to } 11.55) \\
-0.09(-14.18 \text { to } 14) \\
-6.27(-20.88 \text { to } 8.34) \\
-2.48(-15.81 \text { to } 10.85) \\
10.39(-4.65 \text { to } 25.43) \\
12.97(-2.59 \text { to } 28.53) \\
5.22(-9.7 \text { to } 20.14) \\
4.07(-11.48 \text { to } 19.62)\end{array}$ & $\begin{array}{l}0.47 \\
0.39 \\
0.33 \\
0.25 \\
0.26 \\
0.15 \\
0.2 \\
0.24 \\
0.14 \\
0.0 \\
0.29 \\
0.13 \\
0.48 \\
0.58 \\
0.24 \\
0.18\end{array}$ \\
\hline
\end{tabular}

Varying the material densities, irrespective of rearfoot stabilisation, had no effect on impact force. Large interparticipant variability was again found. ${ }^{43}$

In terms of design, a significant moderate attenuating effect was found in favour of a posted moulded orthosis compared with a posted non-moulded orthosis (167.1 N (15.72 to 318.48), ES 0.67) in uninjured participants. ${ }^{30}$ No difference existed between a posted moulded orthosis compared with control in a cohort with history of injury. ${ }^{36}$

\section{Vertical ground reaction force}

Miller et $a^{142}$ reported that their posted moulded orthosis produced less vertical ground reaction force at $10 \%$ and $20 \%$ of the total stance phase. This effect was not apparent when a medially posted $\left(10^{\circ}\right)$ high-density EVA orthosis and a laterally posted $\left(10^{\circ}\right)$ high-density EVA orthosis was compared with control. ${ }^{40}$ Insufficient information was presented to calculate point estimates of effect.

\section{Neuromotor control}

Eight comparisons were found fitting the inclusion criteria. Orthoses were of different designs, including an irregularly surfaced orthosis, and were compared with a control condition. Of these comparisons, two studies (two comparisons) provided enough information to calculate point estimates of effect and their confidence intervals (table 8). ${ }^{44} 45$ The main outcome measure was the amplitude of EMG signal of several muscles of the shank (tibialis anterior (TA), peroneus longus $(\mathrm{PL})$, medial gastrocnemius (MG), lateral gastrocnemius, soleus (Sol), tibialis posterior (TP)) and the thigh (vastus lateralis, vastus medialis, rectus femoris, biceps femoris (BF)). Tomaro and Burdett ${ }^{45}$ also measured the duration of TA EMG signal.

\section{Shank muscles}

Five comparisons were made for each TA, PL and MG. Jogging in a posted moulded orthosis produced significant increases in TA and PL amplitudes and a significant decrease in the amplitude of MG for uninjured participants. ${ }^{46}$ For these participants, posted non-moulded and non-posted moulded orthoses were reported to increase both $\mathrm{PL}$ and $\mathrm{MG}$ in different phases of gait and EMG bandwidths. ${ }^{46}$ Walking in a moulded orthosis posted to $15^{\circ}$ produced an increase of $19 \%$ maximum voluntary contraction (MVC) in PL for participants with no injury. ${ }^{47}$ For participants with current injury, a posted moulded orthosis also significantly increased TA amplitude (37\% of MVC (5.44 to 68.56), ES 0.67). ${ }^{44}$ Walking studies found no effect on MG. Tomaro and Burdett ${ }^{45}$ studied individuals with a history of injury who had worn, for a minimum of 6 months, posted moulded orthoses. They reported no difference between the orthoses and control in TA and PL amplitude as well as no change in TA duration (2.6\% (-2.89 to 8.09), ES 0.41).

Comparisons were also made for Sol and TP. No change in Sol amplitude was reported when participants with no history of injury walked in moulded orthoses posted to $15^{\circ}$ compared 
Table 8 Neuromotor control paradigm comparisons where point estimates of effect and confidence intervals were able to be calculated

\begin{tabular}{|c|c|c|c|c|c|}
\hline Authors & Muscles & Intervention & Comparator & Mean difference (95\% CI) & Effect size (ES) \\
\hline $\begin{array}{l}\text { Nawoczenski and } \\
\text { Ludewig }^{44}\end{array}$ & $\begin{array}{l}\text { TA, MG, VM, VL, BF } \\
(\% \text { MVC) }\end{array}$ & Posted moulded & Control & $\begin{array}{l}\text { TA: } 37.5(5.44 \text { to } 68.56), \text { MG: }-7.6(-23.87 \text { to } 8.67) \text {, } \\
\text { VM: }-2.2(-18.66 \text { to } 14.26), \text { VL: }-4.3(-26.84 \text { to } 18.24) \text {, } \\
\text { BF: }-11.1(-20.31 \text { to }-1.89)\end{array}$ & $0.67,0.26,0.08,0.12,0.68$ \\
\hline
\end{tabular}

LG, lateral gastrocnemius; MVC, maximum voluntary contraction; VL, vastus lateralis; VM, vastus medialis.

with walking in a control. ${ }^{47}$ Similarly, no systematic results were found in TP amplitude in currently injured individuals walking in posted non-moulded, posted moulded and irregular surface orthoses. ${ }^{33}$

\section{Thigh muscles}

Four comparisons were made for the quadriceps and BF. When participants with no history of injury jogged in posted moulded orthoses, all four muscles significantly increased in amplitude during various phases of gait and across different EMG bandwidths. Similar increases were also present in BF when participants wore either posted non-moulded and nonposted moulded orthoses. ${ }^{46}$ These findings are in discordance with a study of currently injured individuals wearing posted moulded orthoses. BF amplitude significantly and moderately (ES 0.68 ) reduced by $11.1 \%$ of MVC (1.89 to 20.31) throughout stance, and there was no change in the activity of vastus medialis or vastus lateralis. ${ }^{44}$

\section{DISCUSSION}

Research has primarily focused on the kinematic paradigm and least on neuromotor control. To the extent that synthesis was possible, data pooling revealed that posted orthoses that were not moulded reduced peak rearfoot eversion and tibial internal rotation in non-injured, whereas moulded orthoses with or without posting produced large reductions in loading rate and vertical impact force.

Data pooling of the kinematic paradigm showed a relatively small effect $\left(2^{\circ}\right)$ in reducing rearfoot eversion and tibial internal rotation using skin markers to record motion, which may well be an overestimate of actual bone motion. ${ }^{48}$ It is currently unknown whether this small motion reduction is clinically beneficial, although Nawoczenski et al ${ }^{6}$ posited that such small changes may be clinically relevant in injured runners because of the potential for cumulative effects from the high volume of repetitive/cyclical motion. More importantly, individual studies showed large confidence intervals, which indicates that practitioners should tailor their approach to each individual's clinical presentation and apply sound clinical reasoning skills when considering this pooled data.

An interesting and unexpected outcome of shock attenuation data was that altering material density had no systematic effect on tibial acceleration, loading rate or vertical impact force, ${ }^{4143}$ whereas orthosis' moulding reduced loading rate ${ }^{3036}$ and may favourably affect vertical impact and ground reaction forces. ${ }^{30} 3642$

Only two neuromotor control studies reported data sufficient to derive point estimates of effect, but pooling was not possible (cohorts too dissimilar). Orthoses seem to increase TA and PL activity, variably influence MG activation levels depending on speed of gait and differentially change MG and thigh muscles contingent on injury status. ${ }^{44} 4647$ Further study is urgently needed in this paradigm.
The methodological quality assessment of the studies in this review identified the main issue as being the non-specific categorisation of injury type. Studies investigating cohorts with past and current injuries included a range of lower limb injuries, thereby making it difficult to apply pooled results to a specific injury in practice.

We only reviewed studies using three-dimensional motion analysis (excluding two-dimensional) because we believe that doing so ensured the most accurate representation of motion. A limitation of this approach is that we may have overlooked meaningful data, though it would seem that this is not the case. ${ }^{252649}$ We also only pooled data from studies using similar orthoses. It must be acknowledged that not all orthoses are exactly the same, so that our pooled point estimates of effect may be underestimates. However, this should be counterbalanced by the increased precision gained by pooling data from a number of studies. Using similar orthoses for pooling strengthens the findings for specific commonly used features of orthoses, such as posting and moulding.

\section{SUMMARY}

The major conclusion of this review is that there is a large amount of variability with regard to how patients respond to orthoses. Meta-analysis showed that an orthosis that is posted without any customisation (or individual moulding) produces greater motion control at the rearfoot and tibia than a control. Orthoses that have been individually contoured are more effective at attenuating loading rate and vertical impact force than if only posted. The majority of the evidence base has been derived from individuals with no history of injury but are likely still useful as rudimentary clinical guides for sports medicine practitioners. Future research needs to focus on neuromotor control effects, especially in those with injury.

Acknowledgements K. Mills and Dr AR Chapman are supported by the Australian Research Council. Financial support for this research was received from the Australian Research Council (Australian Research Council Linkage Project Grant LP0668233).

Funding Australian Research Council, Linkage Project Grant LP0668233, first Floor, 8, Brindabella Circuit, Brindabella Business Park, Canberra Airport Act 2609, Australia.

\section{Competing interests None.}

Provenance and peer review Not commissioned; externally peer reviewed.

\section{REFERENCES}

1. Australian Podiatry Council. Clinical guidlines for orthotic therapy provided by podiatrists. 1998. http://www.apodc.com.au (accessed March 2009).

2. Landorf K, Keenan AM, Rushworth RL. Foot orthosis prescription habits of Australian and New Zealand podiatric physicians. J Am Pediatr Med Assoc 2001;91:174-83.

3. The American College of Foot and Ankle Orthopedics and Medicine. Prescription custom foot orthoses practice guidelines. 2004. http://www.acfoam. org. (accessed March 2009). 
4. Johanson MA, Donatelli R, Wooden MJ, et al. Effects of three different posting methods on controlling abnormal subtalar pronation. Phys Ther 1994;74:149-58; discussion 158-61.

5. McCulloch MU, Brunt D, Vander Linden D. The effect of foot orthotics and gait velocity on lower limb kinematics and temporal events of stance. J Orthop Sports Phys Ther 1993;17:2-10.

6. Nawoczenski DA, Cook TM, Saltzman CL. The effect of foot orthotics on threedimensional kinematics of the leg and rearfoot during running. J Orthop Sports Phys Ther 1995;21:317-27.

7. McPoil TG, Hunt GC. Evaluation and management of foot and ankle disorders: present problems and future directions. J Orthop Sports Phys Ther 1995;21:381-8.

8. Nawoczenski DA, Janisse DJ. Foot orthoses in rehabilitation-what's new. Clin Sports Med 2004;23:157-67.

9. Nigg BM, Nurse MA, Stefanyshyn DJ. Shoe inserts and orthotics for sport and physical activities. Med Sci Sports Exerc 1999;31:S421-8.

10. Nigg BM, Wakeling JM. Impact forces and muscle tuning: a new paradigm. Exerc Sport Sci Rev 2001;29:37-41.

11. Stacoff A, Reinschmidt C, Nigg BM, et al. Effects of foot orthoses on skeletal motion during running. Clin Biomech (Bristol, Avon) 2000;15:54-64.

12. Razeghi M, Batt ME. Biomechanical analysis of the effect of orthotic shoe inserts: a review of the literature. Sports Med 2000;29:425-38.

13. Stefanyshyn DJ, Hettinga BA. Running injuries and orthotics. Int Sport Med J 2006;7:13

14. Bobbert MF, Yeadon MR, Nigg BM. Mechanical analysis of the landing phase in heel-toe running. J Biomech 1992;25:223-34.

15. Hohmann E, Wörtler K, Imhoff AB. MR imaging of the hip and knee before and after marathon running. Am J Sports Med 2004;32:55-9.

16. Nigg, BM. Impact forces in running. Curr Opin Orthop 1997;8:43-7.

17. Nigg BM. The role of impact forces and foot pronation: a new paradigm. Clin $J$ Sport Med 2001;11:2-9.

18. Collins N, Bisset L, McPoil T, et al. Foot orthoses in lower limb overuse conditions: a systematic review and meta-analysis. Foot Ankle Int 2007;28:396-412

19. Hatton AL, Dixon J, Rome K, et al. Effect of foot orthoses on lower limb muslce activitation: a critical review. Phys Ther Rev 2008;13:280-93.

20. McMillan A, Payne C. Effect of foot orthoses on lower extremity kinetics during running: a systematic literature review. J Foot Ankle Res 2008;1:13.

21. Murley GS, Landorf KB, Menz HB, et al. Effect of foot posture, foot orthoses and footwear on lower limb muscle activity during walking and running: a systematic review. Gait Posture 2009;29:172-87.

22. Kovács I, Tihanyi J, Devita P, et al. Foot placement modifies kinematics and kinetics during drop jumping. Med Sci Sports Exerc 1999;31:708-16.

23. Tillman MD, Hass CJ, Chow JW, et al. Lower extremity coupling parameters during locomotion and landings. J Appl Biomech 2005;21:359-70.

24. Eng JJ, Winter DA. Kinetic analysis of the lower limbs during walking: what information can be gained from a three-dimensional model? J Biomech 1995:28:753-8.

25. McClay I, Manal K. The influence of foot abduction on differences between two-dimensional and three-dimensional rearfoot motion. Foot Ankle Int 1998;19:26-31.

26. Areblad M, Nigg BM, Ekstrand J, et al. Three-dimensional measurement of rearfoot motion during running. J Biomech 1990;23:933-40.

27. Downs SH, Black N. The feasibility of creating a checklist for the assessment of the methodological quality both of randomised and nonrandomised studies of health care interventions. J Epidemiol Community Health 1998:52:377-84.
28. Hopkins W. A new view of statistics. 2007. http://www.sportsci.org/resource/ stats/index.html. (accessed March 2009).

29. Zifchock RA. Davis I. A comparison of semi-custom and custom foot orthotic devices in high- and low-arched individuals during walking. Clin Biomech (Bristol, Avon) 2008:23:1287-93.

30. Mündermann A, Nigg BM, Humble RN, et al. Foot orthotics affect lower extremity kinematics and kinetics during running. Clin Biomech (Bristol, Avon) 2003;18:254-62.

31. Nigg BM, Stergiou P, Cole G, et al. Effect of shoe inserts on kinematics, center of pressure, and leg joint moments during running. Med Sci Sports Exerc 2003;35:314-19.

32. Branthwaite HR, Payton CJ, Chockalingam N. The effect of simple insoles on three-dimensional foot motion during normal walking. Clin Biomech (Bristol, Avon) 2004;19:972-7.

33. Stacoff A, Kramers-de Quervain I, Dettwyler, M, et al. Biomechanical effects of foot orthoses during walking. The Foot 2007;17:143-53.

34. Nigg BM, Khan A, Fisher V, et al. Effect of shoe insert construction on foot and leg movement. Med Sci Sports Exerc 1998;30:550-5.

35. Williams DS 3rd, McClay Davis I, Baitch SP. Effect of inverted orthoses on lower-extremity mechanics in runners. Med Sci Sports Exerc 2003;35:2060-8.

36. MacLean CL, Davis IS, Hamill J. Short- and long-term influences of a custom foot orthotic intervention on lower extremity dynamics. Clin J Sport Med 2008;18:338-43.

37. MacLean C, Davis IM, Hamill J. Influence of a custom foot orthotic intervention on lower extremity dynamics in healthy runners. Clin Biomech (Bristol, Avon) 2006;21:623-30

38. Eng JJ, Pierrynowski MR. The effect of soft foot orthotics on three-dimensional lower-limb kinematics during walking and running. Phys Ther 1994;74:836-44.

39. Stackhouse CL, Davis IM, Hamill J. Orthotic intervention in forefoot and rearfoot strike running patterns. Clin Biomech (Bristol, Avon) 2004:19:64-70.

40. Nester CJ, van der Linden ML, Bowker P. Effect of foot orthoses on the kinematics and kinetics of normal walking gait. Gait Posture 2003:17:180-7.

41. Butler RJ, Davis IM, Laughton CM, et al. Dual-function foot orthosis: effect on shock and control of rearfoot motion. Foot Ankle Int 2003:24:410-14.

42. Miller CD, Laskowski ER, Suman VJ. Effect of corrective rearfoot orthotic devices on ground reaction forces during ambulation. Mayo Clin Proc 1996:71:757-62.

43. Nigg BM, Herzog W, Read LJ. Effect of viscoelastic shoe insoles on vertical impact forces in heel-toe running. Am J Sports Med 1988;16:70-6.

44. Nawoczenski DA, Ludewig PM. Electromyographic effects of foot orthotics on selected lower extremity muscles during running. Arch Phys Med Rehabil 1999;80:540-4.

45. Tomaro J, Burdett RG. The effects of foot orthotics on the EMG activity of selected leg muscles during gait. J Orthop Sports Phys Ther 1993:18:532-6.

46. Mündermann A, Wakeling JM, Nigg BM, et al. Foot orthoses affect frequency components of muscle activity in the lower extremity. Gait Posture 2006;23:295-302

47. Murley GS, Bird AR. The effect of three levels of foot orthotic wedging on the surface electromyographic activity of selected lower limb muscles during gait. Clin Biomech (Bristol, Avon) 2006:21:1074-80.

48. Reinschmidt C, Van Den Bogert, AJ, Lundberg A, et al. Tibiofemoral and tibiocalcaneal motion during walking: external vs. skeletal markers. Gait Posture 1997;6:98-109.

49. Cornwall MW McPoil TG. Comparison of 2-dimensional and 3-dimensional rearfoot motion during walking. Clin Biomech (Bristol, Avon) 1995:10:36-40. 